\title{
Chemical composition and antimicrobial and antioxidant activities of essential oils of Polytrichum commune (Hedw.) and Antitrichia curtipendula (Hedw.) Brid. grown in Turkey
}

\author{
Tayyibe Beyza Yucel (iD) $1{ }^{*}$
}

${ }^{1}$ Department of Medical Services and Techniques, Vocational School of Health Services, Giresun University, 28200, Giresun, Turkey

\begin{abstract}
The aim of this study is to analyze the volatile composition and antimicrobial and antioxidant activities of the essential oils of Polytrichum commune and Antitrichia curtipendula. The essential oils obtained by hydrodistillation (HD) from each species were identified by GC-MS/FID. The main components were biformene $(13.06 \%), \alpha$-pinene $(6.53 \%)$, and bornyl acetate $(8.10 \%)$ in $P$. commune. Nonanal and tetradecanal as major compounds were $19.96 \%$ and $20.23 \%$ in $A$. curtipendula essential oils, respectively. Antioxidant activity of obtained essential oils was evaluated using in-vitro antioxidant models. There was no significant difference within the groups according to DPPH activity. Also, the essential oil from $P$. commune showed higher metal-ion chelating activities than that of the essential oil of $A$. curtipendula. Metal-ion chelating activities varied between $4.1 \%$ and $67.4 \%$ at the $800 \mu \mathrm{g} / \mathrm{mL}$ concentration, respectively. The antimicrobial activity was tested by a minimal inhibition concentration test. Each moss species showed good antimicrobial activity against microorganisms according to the results of minimal inhibition concentration experiments.
\end{abstract}

\section{ARTICLE HISTORY}

Received: May 30, 2021

Revised: July 20, 2021

Accepted: Aug, 142021

\section{KEYWORDS}

Mosses,

Hydro-distillation, GC-MS/FID,

Antimicrobial activity, Antioxidant activity

\section{INTRODUCTION}

Bryophytes, divided into three classes; namely, Bryophyta (mosses, 14000 species), Marchantiophyta (liverworts, 6000 species), and Anthocerotophyta (hornworts, 300 species), have about 23000 species in the worldwide and comprise the second largest group of plants after Magnoliophyta - the flowering plants (350000 species) (Asakawa et al., 2013; Asakawa \& Ludwiczuk, 2018; Tonguç-Yayıntaş \& İrkin, 2017). Bryophytes spread all over the world from the deserts to the glaciers, except for the seas (Chandra et al., 2017). Bryophytes are used in several sectors varying from aquatic bioindicators to treatment of waste or from radioactivity indicator to the treatment of packing (Asakawa, 2007).

The mosses are represented by approximately 25000 taxa around the world (Smith, 2004). In the previous studies, despite their broad coverage, the mosses have been unable to preserve their actual place as a prior research. Mosses are used for biomonitoring/bioindicator of waters

\footnotetext{
*CONTACT: Tayyibe Beyza YÜCEL $\varangle$ beyza.yucel@giresun.edu.tr $\cong$ Department of Medical Services and Techniques,Vocational School of Health Services, Giresun University, 28200, Giresun, Turkey
} 
and air pollution in addition to its use for the determination of heavy metal accumulation (Harmens et al., 2007). Lately due to the fact that algae have new and/or bioactive compounds, there has been an increase in the number of pharmacological studies recently (Yayıntaş et al., 2019; Wang et al., 2017). Also, mosses possess various natural products that exhibit biological activity and are used as food supplements or spices and medicals. That moss species have a wide variety of substances of active metabolite makes it possible to use it as an antioxidant as well as antimicrobial (Dey \& De, 2012; Russel, 2010). The mosses Atrichum undulatum and Mnium hornum produce vitamin E, vitamin K, and plastoquinon, while Dicranum scoparium, Leucobryum species contain prostaglandin-like highly unsaturated fatty acids playing an important role as an antioxidant in the human body (Ichikawa et al., 2008; Tedone et al., 2011). Several mosses species have been used as medicinal plants such as Bryum, Mnium, Philonotis species, and Polytrichum juniperinum by North American Indians to treat burns, bruises, and wounds. Terpenoids are other valuable compounds with antibacterial, antifungal, antiinflammatory, and cytotoxic activities (Chen et al., 2018). $\beta$-cyclocitral, $\beta$-ionone, and geosmin are the most common monoterpenoids detected in mosses while Mnium, Taxiphyllum, Plagiothecium, Homalia, and Plagiomnium genus of mosses contain the volatile terpenoids (Asakawa, 1995).

Polytrichum commune as moss class consumed as boiled tea was chosen as the study material for this specific study because it is used in the treatment of many diseases such as wound healing, antipyretic, antidotal activity, dissolving kidney and gallbladder stones, antipyretic and antipyretic, and colds (Chandra et al., 2017; Hallingback et al., 2000; Greeshma $\&$ Murugan 2018). There are a few reports on the antibacterial, cytotoxicity, and antimicrobial activities of solvent extract of Polytrichum commune grown in different parts of the world including Turkey (Klavina et al., 2015; Nikolajeva et al., 2012; Sevim et al., 2017).

Antitrichia curtipendula is used to prepare moss costumes during the annual festival to celebrate important historical wars in Spain (Mártinez-Abaigar \& Núňez-Olivera, 2001) and this species is reported to be used today for packaging mushrooms in the Pacific Northwest (Glime, 2007). Antitrichia curtipendula was chosen as another moss species in this study because there are not many studies about the antioxidant and antimicrobial activity of this moss in the literature (T. Yayıntaş et al., 2019).

In different studies to date, approximately 3000 essential oils have been described from plants that include mosses by using various methods. The number of studies investigating the content, quality, quantity, and biological activities of essential oils has been increasing, especially in recent years due to the fact that they are both cheaply available sources rich in polyunsaturated fatty acids (Bayaz, 2017; Morteza-Semnani et al., 2012) and also they are effective antimicrobial used in the livestock industry and pharmacology as well as in the fields of cosmetics, perfumery, aromatherapy, and soft drinks due to some components it contains (Şahin et al., 2004; Öztürk \& Özbek, 2005).

We used mosses species of Polytrichum commune and Antitrichia curtipendula in this study. In Turkey, there are three species of Polytrichum genus that belong to Polytrichaceae family and two species of Antitrichia genus that belong to Leucodontaceae family. The essential oils of these species were extracted with hydro-distillation using a Clevenger apparatus. Antimicrobial activity of essential oils was examined by microdilution methods against Escherichia coli ATCC25922, Enterococcus faecalis ATCC29212, Staphylococcus aureus ATCC25923, Pseudomonas aeruginosa ATCC27853, and Streptococcus mutans. The antioxidant capacity of essential oils was determined by DPPH scavenging assay and metal-ion chelating assay. Chemical compositions of essential oils were analyzed using GC-MS/FID. Each biological activity test was done twice in duplicate and the results are expressed as mean 
\pm standart deviation (SD). The statistical analysis was performed using a one-way ANOVA ( $p$ $<0.05)$.

\section{MATERIAL and METHODS}

\subsection{Plant Material}

In this study, the fresh moss materials were separated and divided into small pieces. The leaves of $P$. commune were collected on 23rd March 2018 from Taflancik Village, Hayrat, Trabzon, Turkey at an altitude of $478 \mathrm{~m}$. A. curtipendula (Hedw.) was collected on 20th March 2018 from National Park of Altindere Valley, Macka, Trabzon, Turkey at an altitude of $848 \mathrm{~m}$. Voucher specimens were deposited in the Herbarium of the Department of Biology, Karadeniz Technical University, Turkey, respectively (KTUB 1614, KTUB 1608).

\subsection{Isolation of Essential Oils}

The essential oils from each moss species (approximately $50 \mathrm{~g}$ each) were subjected to hydrodistillation for $3 \mathrm{~h}$ using a Clevenger type apparatus with the cooling bath $\left(12{ }^{\circ} \mathrm{C}\right)$ system $(4 \mathrm{~h})$ (yields: $0.13 \%$ and $0.11 \%(\mathrm{v} / \mathrm{w})$, respectively). The obtained oils were dissolved in HPLC grade $n$-hexane $(0.5 \mathrm{~mL})$ and dried over anhydrous sodium sulphate and stored at $4-6{ }^{\circ} \mathrm{C}$ in a sealed brown vial. $1 \mu \mathrm{L}$ of the essential oils was directly injected separately into the GC-MS instrument.

\subsection{GC-MS Analysis of Essential Oils}

The GC-MS analysis was performed using Shimadzu 2010 Plus gas chromatograph coupled to a Shimadzu QP2010 Ultra mass selective detector. The gas chromatography-flame ionization detector (GC-FID) was used. The fibre containing the extracted aroma compounds was injected into GC/MS injector. The split mode was used. The separation was performed by means of a Restek Rxi-5MS capillary column, $60 \mathrm{~m}$ length, $0.25 \mathrm{~mm}$ i.d., and a $0.25 \mu \mathrm{m}$ phase thickness. The oven program was as follows: Initial temperature was $60^{\circ} \mathrm{C}$ for $2 \mathrm{~min}$, which was increased to $240{ }^{\circ} \mathrm{C}$ at $3{ }^{\circ} \mathrm{C} \min ^{-1} .250{ }^{\circ} \mathrm{C}$ was maintained for 4 min. Helium $(99.999 \%)$ was used as carrier gas with a constant flow-rate of $1 \mu \mathrm{L} \mathrm{min}{ }^{-1}$. Detection was carried out in electronic impact mode (EI) and ionization voltage was fixed to $70 \mathrm{eV}$. Scan mode $(40-450 \mathrm{~m} / \mathrm{z})$ was used for mass acquisition. The volatile compounds were identified by comparison with the mass spectra of the two libraries (FFNSC1.2 and W9N11) and using the standard compounds ( $\beta$ pinene, camphene, limonene oxide, isopinocarveol, 1-terpinen-4-ol, $\beta$-ionone, caryophyllene oxide, biformene, and nonanal) (Renda et al., 2019).

\subsection{Antioxidant Activity}

\subsubsection{Measurement of metal-ion chelating capacity}

The experiments as to the chelation of ferrous ions by the essential oils were performed as described by Decker and Welch. Different concentrations of essential oil (25, 50, 100, 200, 400, and $800 \mu \mathrm{g} / \mathrm{mL}$ ) were added to the reaction mixture (Decker \& Welch, 1990). The absorbance of the reaction mixture was measured at $562 \mathrm{~nm}$. EDTA and Trolox were used as standards in the same concentration of essential oils. The percentage of chelating capacity of the test sample was calculated as follows:

$$
\text { Chelating capacity } \%=\left[\left(\mathrm{A}_{1}-\mathrm{A}_{2}\right) / \mathrm{A}_{1} \times 100\right]
$$

where $A_{1}$ is the absorbance of control and $A_{2}$ is the absorbance in the presence of essential oil or EDTA.

\subsubsection{DPPH scavenging activity assay}

The antioxidant activity of each species' essential oil was first determined by measuring the DPPH scavenging ability. The essential oil at various concentrations $(25,50,100,200,400$, 
and $800 \mu \mathrm{g} / \mathrm{mL}$ ) was added to the reaction mixture including DPPH. When DPPH reacts with an antioxidant in the essential oil that can donate hydrogen, it gets its reduced form as the resulting decrease in absorbance at $517 \mathrm{~nm}$ was recorded using a UV-Vis spectrophotometer (Jasco, V-630, Tokyo, Japan) (B.Williams et al., 1995). In this study, Trolox and BHT were used as antioxidant standards. DPPH scavenging activities of the test samples were calculated as follows:

$$
\operatorname{DPPH}(\%)=100-\left(\mathrm{A}_{0}-\mathrm{A}_{1} / \mathrm{A}_{0} \times 100\right)
$$

\subsection{Antimicrobial Activity}

The essential oils showed moderate antibacterial activity against three gram-positive (Staphylococcus aureus ATCC25923, Enterococcus faecalis ATCC29212 and S. mutans) and two gram-negative bacteria (Escherichia coli ATCC25922 and Pseudomonas aeruginosa ATCC27853). Due to the presence of activity in antimicrobial activity studies against gram positive and gram negative microorganisms of these mosses in previous studies, an antimicrobial activity against $E$. coli, $S$. mutans, E. faecalis, $P$. aeruginosa, and $S$. aureus as microorganisms with different ATCC numbers was preferred in this study. Antibacterial susceptibility testing was performed according to the CLSI laboratory standards for broth microdilution assays (CLSI, 2012). For this purpose, antibiotic stock solutions were prepared for the antibiotic test and serial dilutions were made in separate tubes from here. An overnight culture on a nonselective medium such as bloody agar was used in the experiment. A standard inoculum of $0.5 \mathrm{McF}$ arland units (108 colony forming units $/ \mu \mathrm{L})$ was prepared in MRS broth. It was diluted 1:30 (5x $106 \mathrm{CFU} / \mathrm{mL})$ and $50 \mu \mathrm{L}(2.5 \times 105 \mathrm{CFU} / \mathrm{mL})$ was inoculated into each well excluding the control well. Therefore, bacteria inoculum of approximately $2.5 \times 105$ $\mathrm{CFU} / \mathrm{mL}$ was adjusted in a final volume of $100 \mu \mathrm{L}$ in each well. MHB was used in bacterial suspension and antibiotic dilutions were prepared by DMSO. A well of each plate was used as a reproductive control and no antibiotics were added. A well of each plate was used as a sterilization control and included only the broth. The same antibiotics stock solutions and dilutions of the same antibiotics were analysed on appropriate ATCC strains in another plate for the quality control of the experiment. The plates were incubated at $35-37{ }^{\circ} \mathrm{C}$ for 24 hours in a normal atmosphere. Ampicillin $(10.000 \mu \mathrm{g} / \mathrm{mL})$, fluconazole $(5.000 \mu \mathrm{g} / \mathrm{mL})$, and streptomycin $(10.000 \mu \mathrm{g} / \mathrm{mL})$ were used as standard antibacterial and antifungal. When MIC values of quality control strains were appropriate and the results of the reproductive control, the sterilization control, the inoculum purify control, and the inoculum density control were valid, the plates were read by a microplate reader in $600 \mathrm{~nm}$. The results obtained were calculated as $\%$ inhibition.

\subsection{Statistical Analysis}

The obtained essential oils were tested for antioxidant and antimicrobial activities. A statistical package (SPSS version 20.0) was used for data analysis.

\section{RESULTS / FINDINGS}

The chemical composition of essential oils of $P$. commune and A. curtipendula were identified with GC-MS. Altogether, 35 essential compounds were identified with Restek Rxi-5MS column. Chemical compounds were classified into ten classes, viz., monoterpenes, oxygenated monoterpenes, oxygenated monoterpenes related, sesquiterpenes, oxygenated sesquiterpenoids, oxygenated sesquiterpenoids related, diterpene, aldehydes, carboxyllic acids, and others.

In this study, metal ion chelating activity of essential oil of $P$. commune was found to be more effective than that of the essential oil of A. curtipendula. Both of the essential oils represented similar DPHH and antimicrobial activity with no significant difference within the group. 


\subsection{Chemical Composition of Essential Oils}

Both the $P$. commune and $A$. curtipendula extracted the identified compounds in respective orders starting with a total of eight monoterpenes $(30.31 \%, 1.11 \%)$, three oxygenated monoterpenes $(3.42 \%,-)$, eight oxygenated monoterpenes related $(19.25 \%, 18.22 \%)$, three sesquiterpenes $(2.86 \%, 1.44 \%)$, three oxygenated sesquiterpenoids $(5.83 \%,-)$, oxygenated sesquiterpenoids related $(9.99 \%, 14.26 \%)$, one diterpene $(16.06 \%,-)$, three aldehydes (-, $44.21 \%)$, two carboxyllic acid $(10.76 \%,-)$, and four others compounds $(-, 8.37 \%)$, respectively (Table 1).

In $P$. commune essential oil, respectively twenty-five components were identified (Table 1), representing almost $95.48 \%$ of total oils. The main components were biformene $(13.06 \%)$, hexahydro farnesyl acetone $(9.99 \%),(9 Z, 12 Z)$-octadecadienoic acid $(9.51 \%)$, bornyl acetate $(8.10 \%)$, and $\alpha$-pinene (6.53\%), respectively. Biformene, a labdane-type diterpene was reported in Bazzania francana, which is a moss-like plant (Metoyer et al., 2018). It is known that the labdane diterpenes have been shown to possess cardiovascular effects, anti-fungal activity, and anti-inflammatory and cytotoxic effects (Demetzos et al., 2001; Lahlou et al., 2007). In essential oil components of A. curtipendula, fifteen components were characterized, representing almost $85.61 \%$ of the essential oil (Table 1). The major components were tetradecanal (20.23\%), nonanal (19.96\%), hexahydrofarnesyl acetone $(14.26 \%)$, and $\beta$-ionone $(10.43 \%)$. Generally, the number of essential components in the oil of $P$. commune is more than that in $A$. curtipendula.

Table 1. Chemical composition of essential oils of mosses.

\begin{tabular}{|c|c|c|c|c|c|c|}
\hline Number & $\begin{array}{c}\text { Retention } \\
\text { time }^{\mathrm{a}}\end{array}$ & Compounds & $\begin{array}{c} \\
\text { A } \\
\% \text { Area } \\
\end{array}$ & $\begin{array}{c}\text { B } \\
\% \text { Area } \\
\end{array}$ & 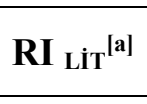 & $\mathbf{R} \mathbf{I}^{[\mathbf{b}]}$ \\
\hline \multicolumn{7}{|c|}{ Monoterpenes } \\
\hline 1 & 6.90 & $\alpha$-pinene & 6.53 & - & 939 & 935 \\
\hline 2 & 7.36 & Camphene & 6.31 & - & 956 & 961 \\
\hline 3 & 8.30 & $\beta$-pinene & 3.78 & - & 979 & 982 \\
\hline 4 & 9.74 & Limonene & 1.45 & - & 1029 & 1033 \\
\hline 5 & 10.03 & $Z$ - $\beta$-Ocimene & 1.75 & - & 1037 & 1042 \\
\hline 6 & 10.25 & $E$ - $\beta$-Ocimene & 6.48 & - & 1050 & 1050 \\
\hline 7 & 11.40 & $m$-Cymenene & 2.46 & - & 1085 & 1083 \\
\hline 8 & 11.94 & Terpinolene & 1.55 & 1.11 & 1089 & 1090 \\
\hline \multicolumn{7}{|c|}{ Oxyganeted monoterpenes } \\
\hline 9 & 14.71 & trans-limonene oxide & 1.09 & - & 1142 & 1141 \\
\hline 10 & 14.90 & Camphor & 1.57 & - & 1146 & 1148 \\
\hline 11 & 18.25 & $\beta$-Cyclocitral & 0.76 & 1.48 & 1221 & 1222 \\
\hline \multicolumn{7}{|c|}{ Oxygenated monoterpenes related } \\
\hline 12 & 16.37 & Terpinen-4-ol & 4.98 & - & 1177 & 1178 \\
\hline 13 & 17.17 & Myrtenal & 0.73 & - & 1196 & 1195 \\
\hline 14 & 17.75 & Verbenone & 1.57 & 3.09 & 1207 & 1205 \\
\hline 15 & 21.08 & Bornyl acetate & 8.10 & - & 1289 & 1291 \\
\hline 16 & 24.93 & Geranyl acetate & 0.89 & - & 1381 & 1377 \\
\hline 17 & 25.70 & $E$ - $\alpha$-Damascenone & - & 1.16 & 1385 & 1387 \\
\hline 18 & 26.63 & $\alpha$-Ionone & - & 2.06 & 1430 & 1432 \\
\hline 19 & 28.47 & $\beta$-Ionone & 2.98 & 10.43 & 1489 & 1492 \\
\hline \multicolumn{7}{|c|}{ Sesquiterpenes } \\
\hline 20 & 24.67 & $\alpha$-cubebene & - & 1.44 & 1351 & 1354 \\
\hline 21 & 26.35 & trans-Caryophyllene & 1.13 & - & 1418 & 1420 \\
\hline 22 & 27.48 & $\alpha$-Humulene & 1.73 & - & 1452 & 1456 \\
\hline
\end{tabular}


Table 1. Continues

\begin{tabular}{|c|c|c|c|c|c|c|}
\hline \multicolumn{7}{|c|}{ Oxyganeted sesquiterpenes } \\
\hline 23 & 31.22 & Caryophyllene oxide & 4.76 & - & 1582 & 1585 \\
\hline 24 & 32.83 & $\alpha$-Cadinol & 1.07 & - & 1654 & 1650 \\
\hline \multicolumn{7}{|c|}{ Oxygenated sesquiterpenoids related } \\
\hline 25 & 36.06 & Hexahydro farnesyl acetone & 9.99 & 14.26 & 1847 & 1848 \\
\hline \multicolumn{7}{|c|}{ Diterpenes } \\
\hline 26 & 41.53 & Biformene & 13.06 & - & 2026 & 2030 \\
\hline \multicolumn{7}{|c|}{ Aldehydes } \\
\hline 27 & 10.21 & Benzene acetaldehyde & - & 2.02 & 1042 & 1046 \\
\hline 28 & 13.28 & Nonanal & - & 19.96 & 1100 & 1101 \\
\hline 29 & 31.30 & Tetradecanal & - & 20.23 & 1613 & 1617 \\
\hline \multicolumn{7}{|c|}{ Carboxyllic acids } \\
\hline 30 & 39.10 & cis-13-eicosenoic acid & 1.25 & - & 1915 & 1918 \\
\hline 31 & 42.13 & $9,12(Z, Z)$-octadecadienoic acid & 9.51 & - & 2149 & 2150 \\
\hline \multicolumn{7}{|c|}{ Others } \\
\hline 32 & 7.28 & Cyclohexanone & - & 2.14 & 952 & 955 \\
\hline 33 & 8.42 & 3-Octanone & - & 2.66 & 984 & 986 \\
\hline 34 & 8.89 & 1-Decene & - & 1.50 & 990 & 991 \\
\hline \multirow[t]{12}{*}{35} & 10.39 & Octanol & - & 2.07 & 1068 & 1065 \\
\hline & & Monoterpenes & 30.31 & 1.11 & & \\
\hline & & Oxygenated Monoterpenes & 3.42 & - & & \\
\hline & & $\begin{array}{l}\text { Oxygenated Monoterpenes } \\
\text { related }\end{array}$ & 19.25 & 18.22 & & \\
\hline & & Sesquiterpenes & 2.86 & 1.44 & & \\
\hline & & Oxygenated Sesquiterpenes & 5.83 & - & & \\
\hline & & $\begin{array}{l}\text { Oxygenated Sesquiterpenes } \\
\text { related }\end{array}$ & 9.99 & 14.26 & & \\
\hline & & Diterpene & 13.06 & - & & \\
\hline & & Aldehydes & - & 44.21 & & \\
\hline & & Carboxyllic acid & 10.76 & - & & \\
\hline & & Others & & 8.37 & & \\
\hline & & Total & 95.48 & 85.61 & & \\
\hline
\end{tabular}

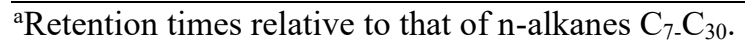

${ }^{\mathrm{b}} \mathrm{RI}$ calculated from retention times relative to that of n-alkanes $\left(\mathrm{C}_{7}-\mathrm{C}_{30}\right)$ on the non-polar Rxi-5MS column.

A: P. commune, B: A. curtipendula

\subsection{Antioxidant and Antimicrobial Activity}

Metals such as iron and copper can form reactive radicals such as superoxide in biological systems due to the formation of redox reactions. Excessive accumulation of these metals causes the accumulation of reactive oxygen and consequently oxidative stress. Oxidative stress causes DNA damage, lipid peroxidation, and protein modification underlying many diseases from many cancers to neurodegenerative diseases (Jomova \& Valko, 2011). Chelation of redoxactive metals prevents oxidative damage avoiding them from forming a redox reaction. The DPPH method is based on the reduction of free radical DPPH in the presence of a hydrogen donating antioxidant. The reaction results in the formation of non-radical DPPH-H and can be measured at $517 \mathrm{~nm}$. Chelation of redox-active metals prevents oxidative damage avoiding them from forming a redox reaction. In this study, maximum metal ion chelating activity was observed in P. commune as the value of $67.42 \pm 0.39$. Essential oils of moss materials represented similar activity $(18.11 \pm 7.14$ and $19.32 \pm 7.04)$ to reduce DPHH (Table 2) with no significant 
difference within the group. The standards of metal chelate and DPPH activities are shown in Table 2.

\pm values indicate the standard deviation. As a result of Anova test, a statistical significance was observed in metal chelate data between samples $(p<0.05)$, while no statistical significance was observed between samples in DPPH data $(p<0.953)$.

Table 2. The 2,2-diphenyl-1-picrylhydrazyl (DPPH) radical scavenging activities and Metal ionchelating of essential oils obtained from $P$. commune and A. curtipendula. (Inhibition $\% \pm \mathrm{SD}$ )

\begin{tabular}{lcc}
\hline & P. commune & A. curtipendula \\
\hline \% DPPH radical scavenging $^{\mathrm{a}}$ & $18.11 \pm 7.14$ & $19.32 \pm 7.04$ \\
\% Metal ion-chelating $^{\mathrm{b}}$ & $67.42 \pm 0.39$ & $4.17 \pm 040$ \\
BHT & & $94.69 \pm 0.04$ \\
Trolox & & $90.57 \pm 0.06$ \\
EDTA & & $97.06 \pm 0.01$ \\
\hline
\end{tabular}

${ }^{a}$ Values are given as mean \pm S.D. $(\mathrm{n}=3)$, and there is no significant difference at $p<0.05$.

${ }^{\mathrm{b}}$ Values are given as mean \pm S.D. $(\mathrm{n}=3)$, and considered to be significantly different at $p<0.05$.

The essential oils showed moderate antibacterial activity against three gram-positive $(S$. aureus, E. faecalis and S. mutans) and two gram-negative bacteria (E. coli and P. aeruginosa). The $\%$ inhibition values of essential oils from five species determined in a broth microdilution assay are shown in Table 3. According to the results, essential oils from each species showed a potent inhibitory effect on the growth of microorganisms without significant differences between groups. Antimicrobial effect values were found ranging from 91.27 to $95.12 \%$. The essential oils showed higher activities than other microorganisms antibacterial activities against S. mutans, E. faecalis, and P. aeruginosa.

Table 3. Minimal inhibitory concentrations $(\mu \mathrm{g} / \mathrm{mL})$ of essential oils against.

\begin{tabular}{lll}
\hline Microorganism & Sample & \% Inhibition \\
\hline \multirow{2}{*}{ E.coli ATCC 25922 } & P. commune & $94.63 \pm 0.07$ \\
\hline \multirow{2}{*}{ E.faecalis ATCC29212 } & A.curtipendula & $95.09 \pm 0.06$ \\
\hline \multirow{2}{*}{ S. mutans } & P. commune & $94.64 \pm 0.09$ \\
\hline \multirow{2}{*}{ P.aeruginosa ATCC27853 } & A.curtipendula & $94.35 \pm 0.05$ \\
\hline S. commune & $94.91 \pm 0.06$ \\
\cline { 2 - 3 } A.curtipendula & $95.12 \pm 0.09$ \\
\hline
\end{tabular}

${ }^{a}$ Values are given as mean \pm S.D. $(n=3)$ and considered to be significantly different at $p<0.05$.

\section{DISCUSSION and CONCLUSION}

The essential oil of $P$. commune contained biformene-diterpene as a major component (Table 1). Diterpenes are the basis of many biologically active substances such as retinol, retinal, taxol, as well as diterpenoids exert anticancer, antioxidant, and anti-inflammatory effects (Costa et al., 2012; Costa et al., 2014). In this study, the essential oil of $P$. commune represented highly inhibitory effects on microorganism. According to our results it's DPPH activity and metal chelating capacity are the highest (22.84 \pm 7.14 and $67.42 \pm 0.39$, respectively). Therefore, we can say that biformene exhibits antioxidant properties as in the literature (Öztürk, 2008; Öztürk et 
al., 2009). At the same time, according to the findings we obtained, the inhibition effect against microorganisms was quite high as shown in Table 3.

Fu et al. (2009) determined the components by separating the extracts of $P$. commune in methanol and different organic solvents by column chromatography. They were identified as the structures of Ohioensin, Communin B, and Communin A and the new compounds were evaluated for cytotoxicity against a small panel of cancer cell lines. In this study, the essential oil of $P$. commune was identified biformene as new compounds.

In another study by Nikolajeva et al., the antimicrobial activity of aqueous and ethanolic extracts of 11 Bryophyta species including P. commune Hedw. and 9 Marchantiophyta species collected in Latvia was tested against Staphylococcus aureus MSCL 334, Escherichia coli MSCL 332 and Bacillus cereus MSCL 330. Extract of P. commune did not have a significant influence $(p>0.05)$ on the growth of E. coli. The growth of Bacillus cereus was inhibited by the aqueous extracts of $P$. commune (MIC80 was not achieved). Minimal inhibitory concentration of $P$. commune aqueous and ethanolic extracts (in \%) against Staphylococcus aureus was found $>33$ and 30 . In this study, the essential oil of $P$. commune was determined as a good antimicrobial activity against $P$. aeruginosa, E. faecalis, E. coli, and $S$. mutans.

Monoterpenes compounds are known to be found in many plants and exhibit antioxidant, anticancer, antiviral, cardioprotective, and cytotoxic effects (Pirbalouti et al., 2014). According to the previous studies, monoterpenes are the major ingredients in essential oil and moderate antimicrobial activity has been observed against the bacteria $Y$. pseudotuberculosis, $P$. aeruginosa, S. aureus, E. faecalis, B. cereus, and M. smegmatis (Dragomanova et al., 2018; Kozioł et al., 2014; Zielinska-Błajet \& Feder-Kubis, 2020). In our study, the essential oil of $P$. commune contained more monoterpene $(30.31 \%)$ and less oxygenated monoterpenes and oxygenated monoterpenes related $(22.67 \%)$ and represented highly antioxidant and antimicrobial activity against $P$. aeruginosa, S. mutans, E. faecalis, and E. coli. In this respect, it can be said that there are different microorganisms used in this study.

P. commune grown Chinese is used for the treatment of fever, hemostatic, traumatic injury, pneumonia, uterine prolapse, and especially lymphocytic leukemia (Zhonghua, 1999; Mishra et al., 2014). In 2013, Cheng showed that ethyl acetate extract of this species stimulates apoptosis and increases oxidative stress in L1210 cells (Cheng et al., 2013). In another study with methanol extract of $P$. commune, the species have been shown to have an effective antimicrobial effect on $P$. larve isolates (Sevim et al., 2017). These studies support the high antimicrobial activity that this species exhibited in our study.

In the study of Tonguç-Yayıntaş, it was determined that ethanol and methanol extracts of $A$. curtipendula by Soxhlet extraction did not exhibit an antioxidant activity in the analysis by radical scavenging capacity method (DPPH) (Tonguç-Yayıntaş et al., 2019). These results differ from the results of radical scavenging capacity (DPPH) of the essential oil of $A$. curtipendula in our study.

In a study of chemical profile of the methanol and chloroform extracts of $P$. commune by Klavina et al. (2015), sterols were found in comparatively higher concentrations in extract and also high ratio carboxyllic acids as tetradecanoic acid, pentadecanoic acid, and octadecanoic acid were found as determined $(9 Z, 12 Z)$-octadecadienoic acid and cis-13-eicosenoic acid. In this respect, it can be said that there is a similarity between the two studies. In the literature about $P$. commune and $A$. curtipendula, chemical profile of the essential oils of the mosses showed big differences as in our case, which can be explained by the environmentally, locality, and the subspecies of the mosses used. 


\section{Acknowledgments}

The author thanks Prof. Dr. Nevzat Batan for characterization of moss materials and Amasya University Research Laboratory for antimicrobial and antioxidant activity.

\section{Declaration of Conflicting Interests and Ethics}

The authors declare no conflict of interest. This research study complies with research and publishing ethics. The scientific and legal responsibility for manuscripts published in IJSM belongs to the author(s).

\section{Authorship Contribution Statement}

Authors are expected to present author contributions statement to their manuscript such as; Tayyibe Beyza YUCEL: Methodology, Investigation, Resources, Visualization, Formal Analysis, and Writing -original draft.

\section{Orcid}

\section{Tayyibe Beyza YUCEL (iD https://orcid.org/ 0000-0002-2632-8325}

\section{REFERENCES}

Asakawa, Y. (1995). Chemical constituents of the bryophytes. In: Progress in the Chemistry of Organic Natural products. Herz, W., Kirby, W.B., Moore, R.E., Steglich, W., Tamm, Ch. (Eds.), Springer, Vienna, Volume 65, pp. 1-618.

Asakawa, Y., \& Ludwiczuk, A. (2018). Chemical constituents of bryophytes: structures and biological activity. J. Nat. Prod., 81(3), 641-660. http://dx.doi:10.1021/acs.jnatprod.6b010 $\underline{46}$

Asakawa, Y., Ludwiczuk, A., \& Nagashima, F. (2013). Phytochemical and biological studies of bryophytes. Phytochemistry, 91, 52-80. https://doi.org/10.1016/j.phytochem.2012.04.012

Asakawa, Y. (2007). Biologically active compounds from bryophytes. Pure Appl. Chem., 79(4), 557-580. https://doi.org/10.1351/pac200779040557

Bayaz, M. (2014) (In Turkish). Esansiyel yağlar: antimikrobiyal, antioksidan ve antimutajenik aktiviteleri. Academic Food Journal, 12(3), 45-53.

Brand-Williams, W., Cuvelier, M. E., \& Berset, C. (1995). Use of a free radical method to evaluate antioxidant activity. LWT-Food Sci. Technol., 28(1), 25-30. http://dx.doi.org/10.1 016/S0023-6438(95)80008-5

Chandra, S., Chandra, D., Barh, A., Pankaj, Pandey, R.K. \& Sharma, I. P. (2017). Bryophytes: Hoard of remedies, an ethno-medicinal review. J. Tradit. Complement Med., 7(1), 94-98. http://dx.doi.org/10.1016/j.jtcme.2016.01.007

Chen, F., Ludwiczuk, A., Wei, G., Chen, X., C. Stotler, B., \& Bowman, J. L. (2018). Terpenoid secondary metabolites in bryophytes: chemical diversity, biosynthesis and biological functions. Crit. Rev. Plant Sci., 37(2-3), 210-231. https://doi.org/10.1080/07352689.2018.1 482397

Cheng, X., Xiao, Y., Wang, P., Wang, X., Zhou, Y., Yan, H., \& Liu, Q. (2013). The ethyl acetate fraction of Polytrichum commune L. ex Hedw. induced cell apoptosis via reactive oxygen species in L1210 cells. J. Ethnopharmacol., 148(3), 926-933. https://doi.org/10.101 6/j.jep.2013.05.045

Clinical and Labarotory Standarts Institute (CLSI). (2012). Twenty-second informational supplement. Tech. Rep. Fort Wayne, Ind, USA. M100- S22.

Costa, J. P., Ferreira, P. B., D. Sousa, D. P., Jordan, J., \& Freitas, R. M. (2012). Anticonvulsant effect of phytol in a pilocarpine model in mice. Neurosci. Lett., 523(2), 115-118. https://doi.org/10.1016/j.neulet.2012.06.055 
Costa, J. P., Oliveira, G. A. L., Almeida, A. A. C., Islam, M. T., Sousa, D. P., \& Freitas, R. M. (2014). Anxiolytic-like effects of phytol: possible involvement of GABAergic transmission. Brain Res., 1547, 34-42. https://doi.org/10.1016/i.brainres.2013.12.003

Decker, E.A., \& Welch, B. (1990). Role of ferritin as a lipid oxidation catalyst in muscle food. J. Agric. Food Chem., 38(3), 674-677. https://doi.org/10.1021/jf00093a019

Demetzos, C., Dimas, K., Hatziantoniou, S., Anastasaki, T., \& Angelopoulou, D. (2001). Cytotoxic and anti-inflammatory activity of labdane and cis-clerodane type diterpenes. Planta Med., 67(07), 614-618. https://doi.org/10.1055/s-2001-17362

Dey, A., \& De, N.J. (2012). Antioxidative potential of bryophytes: Stress tolerance and commercial perspectives: A Review. Pharmacologia, 3(6), 151-159. https://doi.org/10.556 7/pharmacologia.2012.151.159

Dragomanova, S., Tancheva, L., \& Georgieva, M. (2018). A review: Biological activity of myrtenal and some myrtenal containing medicinal plant essential oils. Scr. Sci. Pharm., 5(2), 22-33. https://doi.org/10.14748/ssp.v5i2.5614

Fu, P., Lin, S., Shan, L., Lu, M., Shen, Y.H., Tang, J., Liu, R.H., Zhang, X., Zhu, R.L., \& Zhang, W.D. (2009). Constituents of the moss Polytrichum commune. J. Nat. Prod., 72(7), 13351357. https://doi.org/10.1021/np800830v

Glime, J.M. (2007). Economic and ethnic uses of bryophytes: in Flora of North America (North Mexico), edited by Flora of North America Editorial Committee. Vol.27, Bryophyta, Part I. Oxford University Press. New York, pp. 14-41.

Greeshma, G.M., \& Murugan K. (2018). Comparison of antimicrobial potentiality of the purified terpenoids from two moss species Thuidium tamariscellum (C. Muell.) Bosch. \& Sande-Lac and Brachythecium buchananii (Hook.) A. Jaeger. J. Anal. Pharm. Res., 7(5), 530-538. https://doi.org/10.15406/japlr.2018.07.00279

Hallingback, T., \& Hodgetts, N. (2000). World Conservation Union; Mosses, Liverworts, and Hornworts. Status Survey and Conservation Action Plan for Bryophytes. IUCN Publication.

Harmens, H., Norris, D.A., Koerber, G.R., Buse, A., Steinnes, E., \& Rühling, A. (2007). Temporal trends in the concentration of arsenic, chromium, copper, iron, nickel, vanadium and zinc in mosses across Europe between 1990 and 2000. Atmos. Environ. 41(31), 6673 6687. https://doi.org/10.1016/j.atmosenv.2007.03.062

Ichikawa, T., Namikawa, M., Yamada, K., Sakai, K., \& Kondo, K. (1983). Novel cyclopentenonyl fatty acids from mosses, Dicranum scoporium and Dicranum japonicum. Tetrahedron Lett., 24(32), 3337-3340. https://doi.org/10.1016/S0040-4039(00)86263-2

Jomova, K., \& Valko, M. (2011). Advances in metal-induced oxidative stress and human disease. Toxicology, 283(2-3), 65-87. https://doi.org/10.1016/j.tox.2011.03.001

Kozioł, A., Stryjewska, A., Librowski, T., Sałat, K., Gaweł, M., Moniczewski, A., \& Lochynski, S. (2014). An overview of the pharmacological properties and potential applications of natural monoterpenes. Mini Rev. Med. Chem., 14(14), 1156-1168. https://doi.org/10.2174/1389557514666141127145820

Klavina, L., Springe, G., Nikolajeva, V., Martsinkevich, I., Nakurte, I., Dzabijeva, D., \& Steinberga, I. (2015). Chemical composition analysis, antimicrobial activity and cytotoxicity screening of moss extracts (Moss Phytochemistry). Molecules, 20(9), 17221-17243. https://doi.org/10.3390/molecules200917221

Lahlou, S., Correia, C. A., Santos, M. V., David, J. M., David, J. P., Duarte, G. P., \& Magalhães, P. J. C. (2007). Mechanisms underlying the cardiovascular effects of a labdenic diterpene isolated from Moldenhawera nutans in normotensive rats. Vascul. Pharmacol., 46(1), 6066. https://doi.org/10.1016/j.vph.2006.06.010

Mártinez-Abaigar, J., \& Núňez-Olivera, E. (2001). The legend and procession of the moss men from Béjar (Salamanca, Spain). J. Bryol., 23, 264-266. https://doi.org/10.1179/jbr.2001.23. $\underline{3.264}$ 
Métoyer, B., Lebouvier, N., Hnawia, E., Herbette, G., Thouvenot, L., Asakawa, Y., \& Raharivelomanana, P. (2018). Chemotypes and biomarkers of seven species of new caledonian liverworts from the bazzanioideae subfamily. Molecules, 23(6), 1353-1360. https://doi.org/10.3390/molecules23061353

Mishra, R., Pandey, V.K., \& Chandra, R. (2014). Potential of bryophytes as therapeutics. Int. J. Pharm. Sci. Res., 5(9), 3584-3593. https://doi.org/10.13040/IJPSR.0975-8232.5(9).3584$\underline{93}$

Morteza-Semnani, K., Saeedi, M., \& Akbarzadeh, M. (2012). Chemical composition and antimicrobial activity of the essential oil of Verbascum thapsus L.. J. Essent. Oil-Bear. Plants, 15(3), 373-379. https://doi.org/10.1080/0972060X.2012.10644063

Nikolajeva V., Liepina, L., Petrina, Z., Krumina, G., Grube, M., \& Muiznieks, I. (2012). Antibacterial activity of extracts from some bryophytes. Adv. Microbiol, 2(3), 345-353. https://doi.org/10.4236/aim.2012.23042

Öztürk, A., \& Özbek, H. (2005). The anti-inflammatory activity of Eugenia caryophyllata essential oil: an animal model of anti-inflammatory activity. Eur. J. Gen. Med., 2(4), 159163. https://doi.org/10.29333/ejgm/82334

Öztürk, M. (2008). Analysis of antioxidant compounds in Micromeria cilicica and M. juliana by HPLC and elucidation of their structures. Doctoral Thesis, Institute of Health Science, İstanbul University, İstanbul, Turkey.

Öztürk, M., Kolak, U., Duru, M.E., \& Harmandar, M. (2009). GC-MS analysis of the antioxidant active fractions of Micromeria juliana with anticholinesterase activity. Nat. Prod. Commun., 4(9), 1271-1275. https://doi.org/10.1177/1934578X0900400923

Pirbalouti, A. G., Mirbagheri, H., Hamedi, B., \& Rahimi, E. (2014). Antibacterial activity of the essential oils of myrtle leaves against Erysipelothrix rhusiopathiae. Asian Pac. J. Trop. Biomed., 4(1), 505-509. https://doi.org/10.12980/APJTB.4.2014B1168

Renda, G., Özel, A., Barut, B., Korkmaz, B., \& Yaylı, N. (2019). The volatile chemical compositions of the essential oil/spme and enzyme inhibitory and radical scavenging activities of solvent extracts and the essential oils from Coronilla orientalis Miller and $C$. varia L. grows in Turkey. Iran. J. Pharm. Sci., 18(4), 1831-1842. https://doi.org/10.22037/ ijpr.2019.1100802

Russell, M.D. (2010). Antibiotic activity of extracts from some bryophytes in South Western British Columbia, Med. Stud. J. Aust., 2(1), 9-14.

Sevim, E., Baş, Y., Çelik, G., Pınarbaş, M., Bozdeveci, A., Özdemir, T., \& A. Karaoğlu, Ş. (2017). Antibacterial activity of bryophyte species against Paenibacillus larvae isolates. Turk. J. Vet. Anim. Sci., 41(4), 521-531. https://doi.org/10.3906/vet-1611-70

Smith, A.J.E. (2004). The Moss flora of Britain and Ireland, Cambridge University Press, edn 2.

Şahin, F., Güllüce, M., Daferera, D., Sökmen, A., Sökmen, M., Polissiou, M., \& Özer, H. (2004). Biological activities of the essential oils and methanol extract of Origanum vulgare ssp. vulgare in the Eastern Anatolia region of Turkey. Food control, 15(7), 549-557. https://doi.org/10.1016/j.foodcont.2003.08.009

Tedone, L., Komala, I., Ludwiczuk, A., Nagashima, F., Ito, T., Mondero, L., \& Asakawa, Y. (2011). Volatile components of selected Japanese and Indonesian liverworts. 55th Symposium on the Chemistry of Terpenes; Essential Oils and Aromatics, Tsukuba, Japan, p. 272-274.

Tonguç-Yayıntas, Ö., Yılmaz, S., \& Sökmen, M. (2019). Determination of antioxidant, antimicrobial and antitumor activity of bryophytes from Mount Ida (Canakkale Turkey). Indian J. Tradit. Knowl., 18(2), 395-401. http://nopr.niscair.res.in/handle/123456789/47066

Tonguç-Yayıntas, Ö., \& İrkim, L. (2017). Secret Beauty of Freshwater: "Aquarium Mosses". J. Aware., 2(3), 523-540. https://journals.gen.tr/joa/article/view/284 
Wang, X., Cao, J., Dai, X., Xiao, J., Wu, Y., \& Wang, Q. (2017). Total flavonoid concentrations of bryophytes from Tianmu Mountain, Zhejiang Province (China): Phylogeny and ecological factors. PloS One., 12(3), 1-10. https://doi.org/10.1371/journal.pone.0173003

Zielinska-Błajet, M., \& Feder-Kubis, J. (2020). Monoterpenes and their derivatives-recent development in biological and medical applications. Int. J. Mol. Sci., 21(19), 7078-7116. https://doi.org/10.3390/ijms21197078

Zhonghua, B. (1999). State administration of traditional chinese medicine of the people's repuclic of China, Shanghai Science Technology Press, Shanghai. pp 22-23, 1999. (in Chinese). 